\title{
Nutritional quality of browse after brush man- agement on cross timbers rangeland
}

\author{
RODERICK B. SOPER, ROBERT L. LOCHMILLER, DAVID M. LESLIE, JR., AND \\ DAVID M. ENGLE
}

\begin{abstract}
Authors are former graduate research assistant, Department of Zoology, Oklahoma State University, Stillwater 74078; associate professor, Department of Zoology, Oklahoma State University; unit leader, U.S. Fish and Wildlife Service, Oklahoma Cooperative Fish and Wildlife Research Unit, Department of Zoology, Oklahoma State University; professor, Department of Agronomy, Oklahoma State University. Reprint requests should be sent to $R L L$.
\end{abstract}

\begin{abstract}
We evaluated seasonal changes in browse quality 5-6 years after experimental manipulations to control unwanted woody vegetation using combinations of herbicide and fire on cross timbers rangeland in central Oklahoma. The study area consisted of two 32-ha replications of untreated controls and 4 brush treatments (tebuthiuron and triclopyr used singly or in combination with periodic prescribed burning); herbicides were applied in 1983 and fires initiated in 1985. Nutritional quality of blackberry (Rubus spp.), coralberry, (Symphoricarpos orbiculatus Moench), roughleaf dogwood (Cornus drummondii Meyer), elm (Ulmus spp.), greenbrier (Smilax spp.), hackberry (Celtis spp.), and smooth sumac (Rhus glabra L.) were assessed by measuring crude protein, in vitro dry matter digestibility, neutral detergent fiber, acid detergent fiber, and moisture content. Crude protein concentrations of browse were $14 \%$ higher on herbicide-treated areas compared to untreated controls and $11 \%$ higher on triclopyr treatments compared to tebuthiuron treatments. In vitro dry matter digestibility was $9 \%$ higher on herbicide-treated areas compared to untreated controls. Fiber constituents and moisture content were not influenced by brush treatments. Prescribed burning combined with herbicide applications did not improve the quality of browse. Our results indicate that browse quality can be improved for whitetailed deer by applications of tebuthiuron or triclopyr and improvements persist for up to 6 years post treatment.
\end{abstract}

Key Words: browse quality, brush management, cross timbers, habitat, nutrition, Odocoileus virginianus, Oklahoma, protein, white-tailed deer

Woody browse comprises a significant proportion of the diet of many species of wildlife, including white-tailed deer (Odocoileus virginianus). In addition, to phenology, the nutritional quality of browse is influenced by species (Cowan et al. 1970), soil type (Hundley 1959), rainfall (Laycock and Price 1970), fire (Dewitt and Derby 1955), amount of canopy cover (Halls and Epps 1969), and a variety of other environmental factors (Robbins and Moen 1975 , Van Soest 1982). Woody vegetation is also frequently managed by mechanical, chemical, and burning techniques on rangeland to increase herbaceous forage production for both livestock and wildlife (Scifres 1980). Management techniques that alter environmental factors can frequently be used to alter the nutritional quality of woody and herbaceous vegetation (Everitt 1983,

\footnotetext{
The authors wish to thank the many graduate students in the Department of Zoology at Oklahoma State University that participated in the collection of browse. W.D. Warde's statistical expertise was also greatly appreciated. Financial support for this research was provided by the Oklahoma Agricultural Experiment Station, National Science Foundation (BSR-8657043), Kerr Foundation, and the Oklahoma Cooperative Fish and Wildlife Research Unit. This is a journal article of the Oklahoma Agricultural Experiment Station.

Manuscript accepted 6 Mar. 1993.
}

Rasmussen et al. 1983, Masters and Scifres 1984).

The cross timbers land resource area is a western extension of the Ozark Plateau oak-hickory ecosystem and accounts for approximately 19 million ha of rangeland in Oklahoma (Garrison et al. 1977 , SCS 1981). Livestock stocking rates are relatively low in the cross timbers region due to low herbaceous forage production. As a result, mechanical and chemical (with and without fire) treatments are routinely used to remove unwanted brush species and increase forage production for livestock (Scifres and Mutz 1978, Scifres et al. 1979, Scifres 1980, Scifres et al. 1981, Scifres et al. 1983, Ivey and Causey 1984, Wood 1988).

Although many landowners are interested in managing whitetailed deer in conjunction with livestock operations, little is known of the effects of range improvement practices used in the cross timbers relative to the nutritional quality of forages important to deer. Our objective was to determine the effects of applications of a systemic herbicide, tebuthiuron ( $\mathrm{N}-[5$-(1,1-dimethylethyl)-1,3,4thiadiazol-2-yl]-N, $\mathrm{N}^{\prime}$-dimethylurea), and a contact herbicide, triclopyr ([3,5,6,-trichlor-2-pyridinyl)oxy]acetic acid), used in conjunction with and without an annual spring burn 5-6 years post treatment on the seasonal nutritional quality of 7 woody browse species. Prescribed fire was used to control secondary regrowth on herbicide-treated areas.

\section{Methods}

\section{Study Area}

The Cross Timbers Experimental Range, located $13 \mathrm{~km}$ southwest of Stillwater, Okla., is a 640-ha research area that was established in 1983 to compare responses of vegetation, livestock, and wildlife to management of woody vegetation. The Experimental Range was divided into 20 adjacent and fenced 32-ha pastures of 4 replications (only 2 replications were sampled) of 4 randomly applied brush treatments and untreated control. The 4 brush treatments included: (1) tebuthiuron; (2) tebuthiuron with annual spring burn; (3) triclopyr; (4) triclopyr with an annual spring burn. A more detailed description of treatments and study area was in Lochmiller et al. (1991). Each herbicide was applied aerially at a rate of $2.2 \mathrm{~kg} \mathrm{ha}^{-1}$ (tebuthiuron, March 1983; triclopyr, June 1983) and annual prescribed burning was applied in April 1985-1987. Description of pre-treatment vegetation (Ewing et al. 1984) and soils (Gray and Stanke 1970) have been published.

Upland hardwood forest, dominated by blackjack oak (Quercus marilandica Muenchh.) and post oak ( $Q$. stellata Wang.), is the primary vegetation type in the area on coarse-textured soils; tallgrass prairie is interspersed on fine-textured soils (Ewing et al. 1984). The upland forest, before treatment, varied from open hardwood overstory with a productive herbaceous understory to completely closed overstory canopy with negligible understory production. Bottomland forest occupies a rather restricted position along drainages. Understory species were dominated by 
coralberry (Symphoricarpos orbiculatus Moench), eastern redcedar (Juniperus virginiana L.), poison ivy (Rhus radicans L.), roughleaf dogwood (Cornus drummondii Meyer), redbud (Cercis canadensis L.), and American elm (Ulmus americana L.). Dominant herbaceous species include little bluestem (Andropogon scoparius Michx.), Indiangrass (Sorghastrum nutans (L.) Nash), western ragweed (Ambrosia psilostachya $\mathrm{DC}$.), and rosette panicgrass (Panicum oligosanthes Schult.) (Ewing et al. 1984).

Changes in the botanical composition of vegetation following tebuthiuron and triclopyr applications, with and without prescribed burning, on the Experimental Range were reported previously (Engle et al. 1991, Stritzke et al. 1991). Briefly, tebuthiuron greatly reduced the hardwood understory and overstory, and increased herbaceous forage production. Triclopyr also reduced the hardwood overstory and moderately increased herbaceous forage production, but a dense overstory of resprouting woody species resulted. Untreated habitats were characterized by a dense woody canopy with little herbaceous cover and moderate amounts of woody understory (Engle et al. 1991, Stritzke et al. 1991). Prescribed burning did not greatly alter the woody vegetation except that it reduced the cover of eastern redcedar (Stritzke et al. 1991), improved gains of stocker cattle (McCollum et al. 1987), and improved the nutritional quality of selected herbaceous forages (Bogle et al. 1989).

\section{Browse Sampling}

We sampled 7 species of browse commonly consumed by whitetailed deer in Oklahoma (Deliberto 1987, Van Vreede 1987, Jenks 1991, Gee et al. 1991): blackberry (Rubus spp.), coralberry (Symphorcarpus orbiculatus Moench), roughleaf dogwood (Cornus drummondii Meyer), elm (Ulmus spp.), greenbrier (Smilax spp.), hackberry (Celtis spp.), and smooth sumac (Rhus glabra L.), Browse was sampled from 2 replications of each experimental treatment in winter (Jan.), spring (Apr.), summer (Jul.), and fall (Oct.) from winter 1988 to spring 1989. Within each treatment replication, browse was sampled on upland (shallow savannah soils) and bottomland (deep sandy hardwood soils) habitat sites. Five $\mathrm{cm}$ of current annual growth of both leaf and stem were randomly collected from 10 locations on 10 individual plants within each habitat site. Samples were composited by habitat site, placed in sample bags, and dried at $52^{\circ} \mathrm{C}$ to a constant weight. Dried samples were ground in a Wiley mill through a $1-\mathrm{mm}$ mesh screen before chemical analyses.

\section{Nutrient Analyses}

Browse samples from each habitat site and treatment replication were analyzed for percentage of crude protein, neutral detergent fiber, acid detergent fiber, in vitro dry matter digestibility, and moisture content. Crude protein was calculated by determining nitrogen concentration of $0.25 \mathrm{~g}$ samples on a rapid Kjeldhal system and multiplying by the correction factor 6.25 (Williams 1984). Concentrations of neutral detergent fiber and acid detergent fiber were estimated as described by Goering and Van Soest (1970). Concentration of hemicellulose was calculated as the difference between acid detergent fiber and neutral detergent fiber. Percent in vitro dry matter digestibility was determined using the acid-pepsin enzymatic digestion procedures as described by Choo et al. (1981). Percent moisture was determined as the proportion of weight lost after oven-drying $\left(52^{\circ} \mathrm{C}\right)$. All values are expressed on a percent dry matter basis with the exception of moisture which we expressed on a live tissue basis.

\section{Statistical Analyses}

Preliminary statistical analyses indicated nutrient levels of browse did not differ between upland and bottomland habitat sites. Subsequently, main and interactive effects of treatment $(n=$ 4; 2 habitat sites per replication and 2 replications per treatment) and season on the nutritional quality of each browse species were examined with a 2-way analysis of variance (ANOVA). When statistical interactions were significant, differences among treatments were examined within a season using 1-way ANOVA. Protected multiple comparisons (LSD) were used to separate treatment differences when ANOVA rejected the null hypothesis that treatments were similar. Specific contrasts were used to compare variation in nutritional quality of browse within brush treatment categories (treated vs. untreated, burned herbicide-treated vs. unburned herbicide-treated, tebuthiuron-treated vs. triclopyrtreated). The Statistical Analysis System (SAS 1985) was used for all statistical procedures. Means were considered statistically different at $P<0.05$.

\section{Results}

Significant seasonal fluctuations in measures of browse quality were evident for all species across the entire study. Crude protein, in vitro dry matter digestibility, and moisture were highest in spring and lowest in winter (Figs. 1 through 7) Conversely, neutral detergent fiber and acid detergent fiber were lowest in spring and highest in winter. Among species, all forage quality indices except in vitro dry matter digestibility were highest for greenbrier; coralberry had the highest in vitro dry matter digestibility.

\section{Crude Protein}

Throughout the study, treatment differences were most apparent for crude protein. Crude protein varied significantly among the 5 treatments for 5 (blackberry, coralberry, elm, greenbrier, and hackberry) of 7 browse species examined. Season $\times$ treatment interactions were significant for crude protein concentrations in coralberry, blackberry, elm, and hackberry. Crude protein concentrations were significantly higher on the 2 triclopyr-treated areas compared to untreated areas compared to untreated controls for blackberry (winter and spring 1989), elm (spring 1988, 1989), and hackberry (spring 1988, 1989, and fall 1988); other comparisons were not significant.

Concentrations of crude protein were significantly higher on herbicide-treated areas compared to untreated controls for 5 (coralberry, blackberry, dogwood, elm, and hackberry) of 7 browse species (Table 1). On average, browse species contained $14 \%$ more crude protein on herbicide-treated areas than controls; differences were most pronounced for elm, which contained $25 \%$ more crude protein on treated areas. Crude protein concentrations were also higher on areas treated with triclopyr compared to tebuthiuron for 6 (coralberry, blackberry, dogwood, elm hackberry, and greenbrier) of 7 browse species (Table 1). Browse from triclopyr-treated areas contained an average of $11 \%$ more crude protein than tebuthiuron-treated areas; differences were most pronounced for greenbrier, which contained about $18 \%$ more protein. Burning influences were limited to crude protein concentrations for elm, which were $6 \%$ higher on burned than unburned areas.

\section{Digestibility}

Percent in vitro dry matter digestibility resembled seasonal and treatment differences for crude protein; however, the main effect of treatment was only significant for blackberry and there was a season $X$ treatment interaction. Percent in vitro dry matter digestibility of blackberry was higher on the 2 triclopyr-treated areas than the 2 tebuthiuron treatments in winter 1988 and spring 1989.

Percent in vitro dry matter digestibility was higher for 5 (blackberry, dogwood, hackberry, greenbrier, and smooth sumac) of 7 species on herbicide-treated areas compared to untreated controls. In vitro dry matter digestibility was $9 \%$ higher on average for browse from treated areas compared to untreated controls; differences were most pronounced for blackberry, which contained about $15 \%$ more protein. Burning had no influence on in vitro dry matter digestibility. 

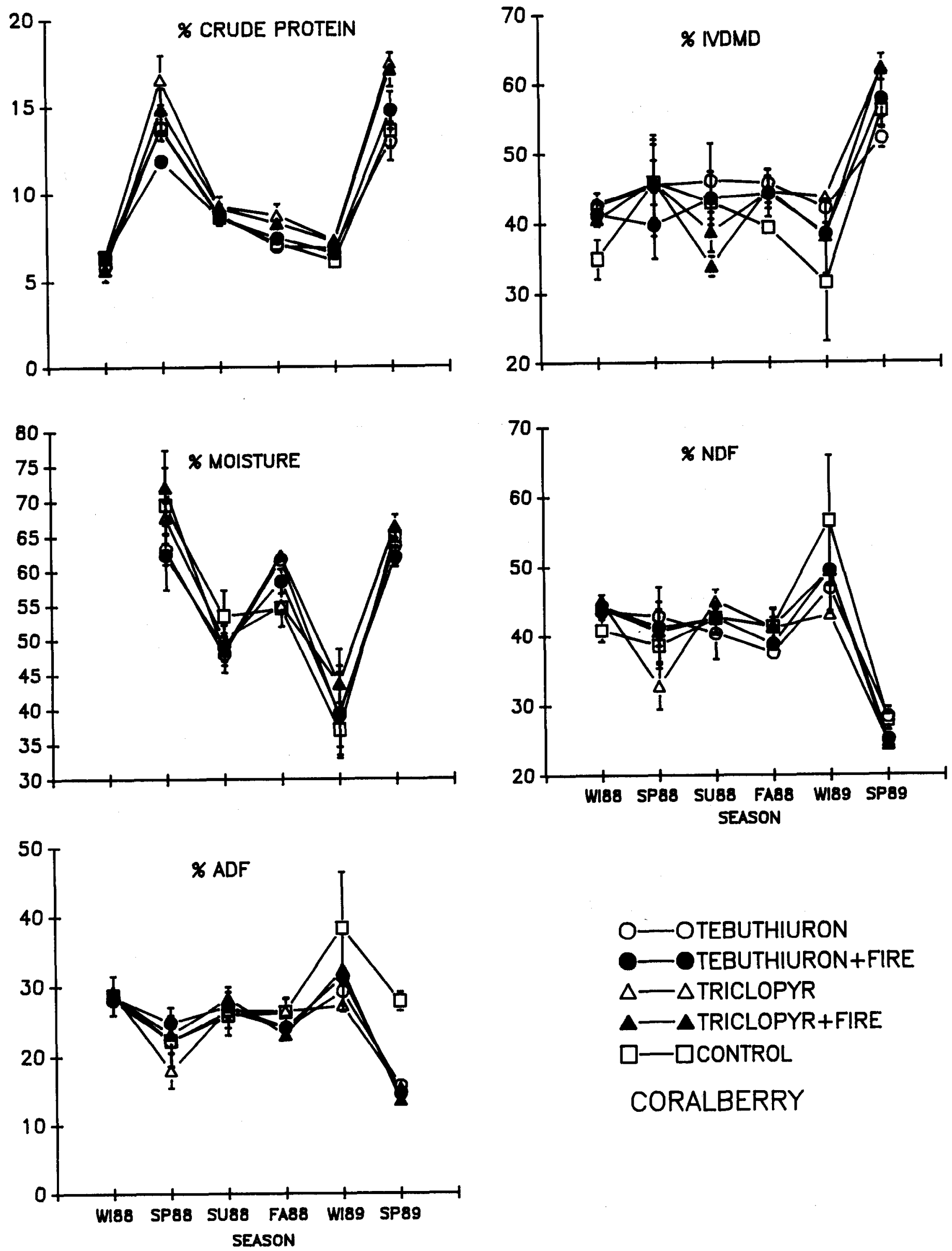
$\triangle-\triangle T R I C L O P Y R$ $\triangle-\triangle$ TRICLOPYR+FIRE $\square-\square C O N T R O L$ CORALBERRY

Fig. 1. Seasonal changes in mean ( $\pm \mathrm{SE}$ ) nutrient composition of coralberry browse as influenced by experimental brush removal using triclopyr or tebuthiuron with and without prescribed fire. The study was conducted on the Cross Timbers Experimental Range during all seasons in 1988 and winter and spring of 1989.

JOURNAL OF RANGE MANAGEMENT 46(5), September 1993 

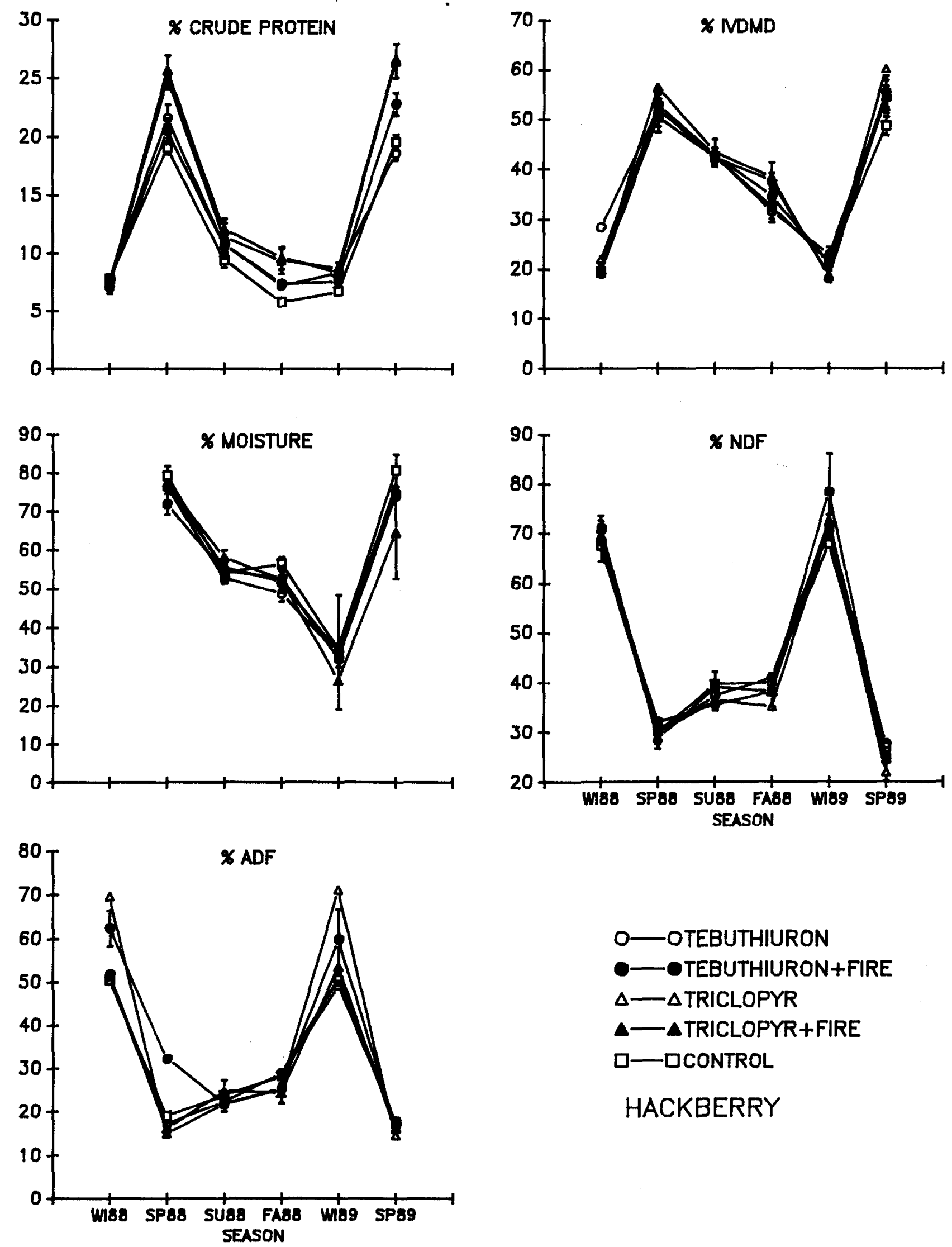

HACKBERRY

Fig. 2. Seasonal changes in mean ( $(S E)$ nutrient composition of hackberry browse as influenced by experimental brush removal using triclopyr or tebuthiuron with and without prescribed fire. The study was conducted on the Cross Timbers Experimental Range during all seasons in 1988 and winter and spring of 1989. 

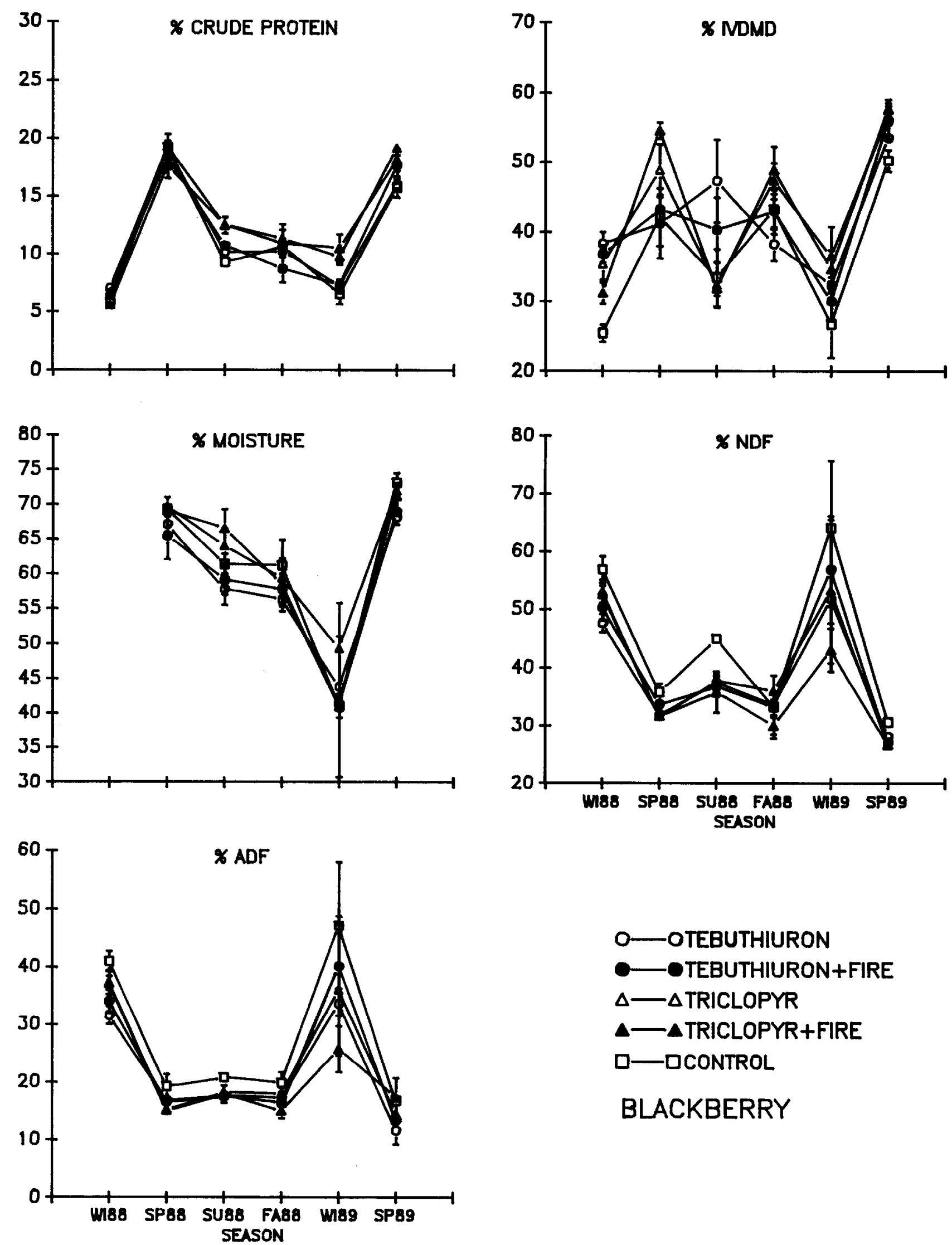

\section{BLACKBERRY}

Fig. 3. Seasonal changes in mean ( \pm SE) nutrient composition of blackberry browse as influenced by experimental brush removal using triclopyr or tebuthiuron with and without prescribed fire. The study was conducted on the Cross Timbers Experimental Range during all seasons in 1988 and winter and spring of 1989. 

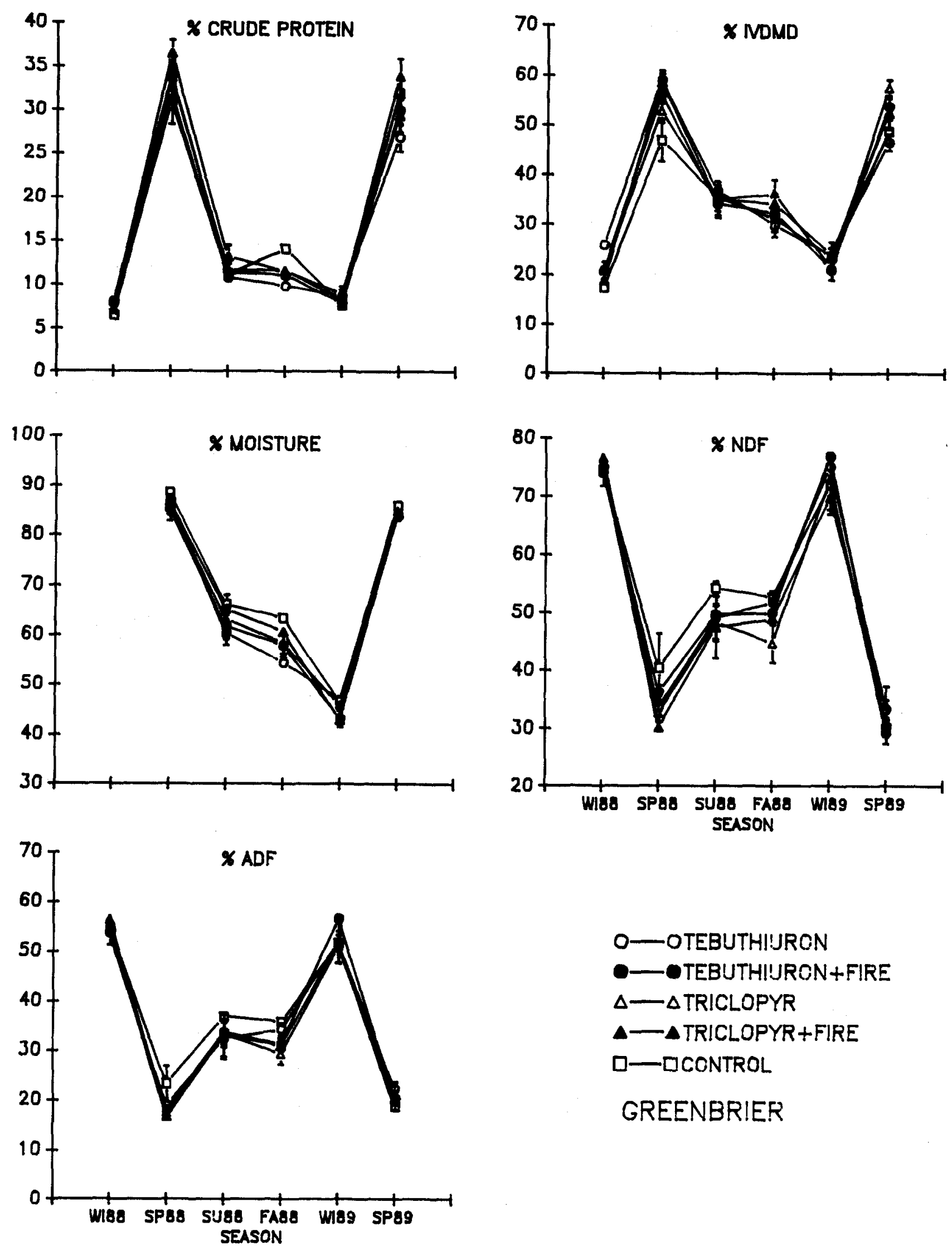

O-OTEBUTHI!URON

- TEBUTHIJRON+FIRE

$\triangle-\triangle T R I C L O P Y R$

$\triangle-\triangle T R I C L O P Y R+F I R E$

口- DCONTROL

GREENBR!ER

Fig. 4. Seasonal changes in mean ( $\pm S E)$ nutrient composition of greenbriar browse as influenced by experimental brush removal using triclopyr or tebuthiuron with and without preseribed fire. The study was conducted on the Cross Timbers Experimental Range during all seasons in 1988 and winter and spring of 1989. 

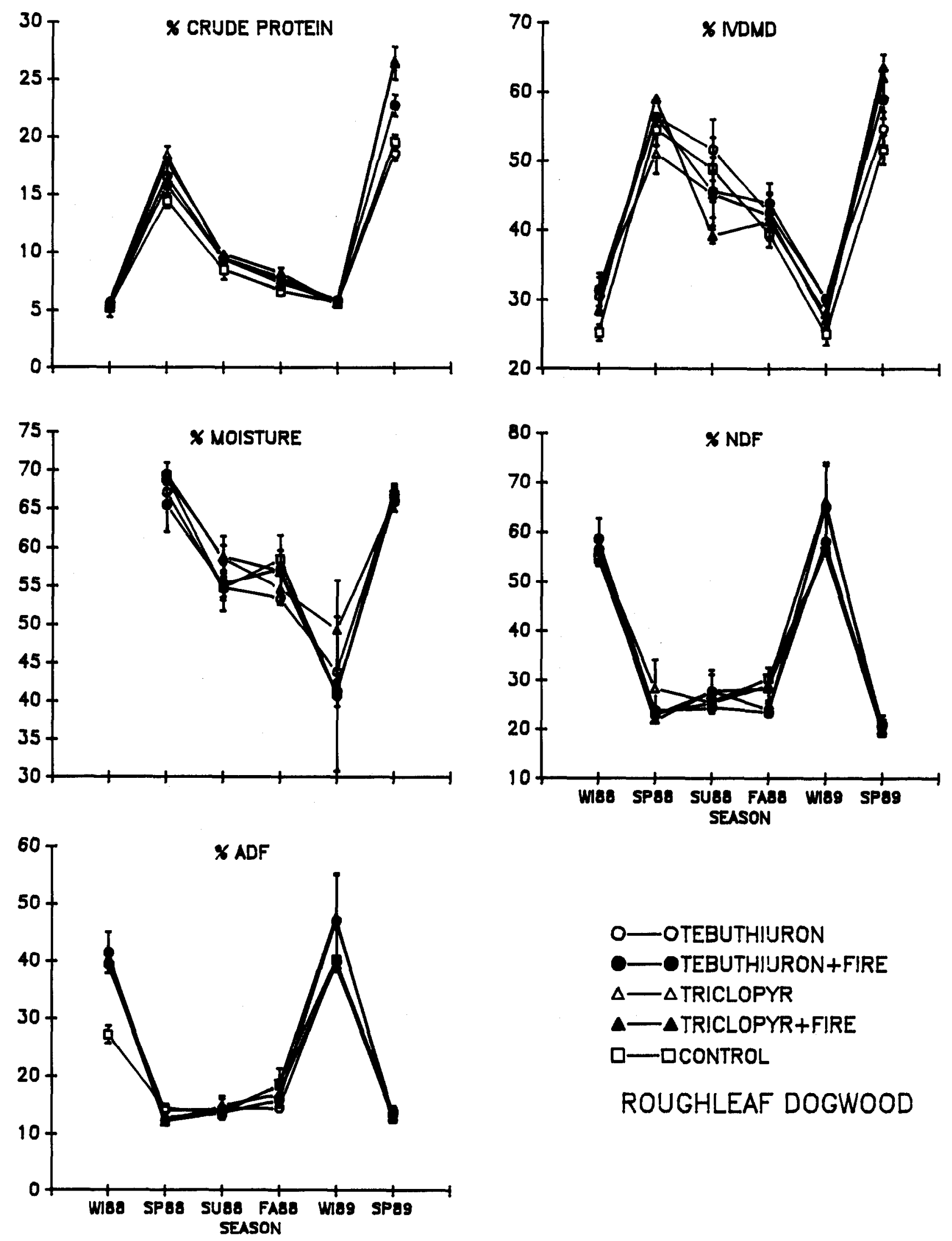

Fig. 5. Seasonal changes in mean ( \pm SE) nutrient composition of dogwood browse as influenced by experimental brush removal using triclopyr or tebuthluron with and without prescribed fire. The study was conducted on the Cross Timbers Experimental Range during all seasons in 1988 and winter and spring of 1989. 

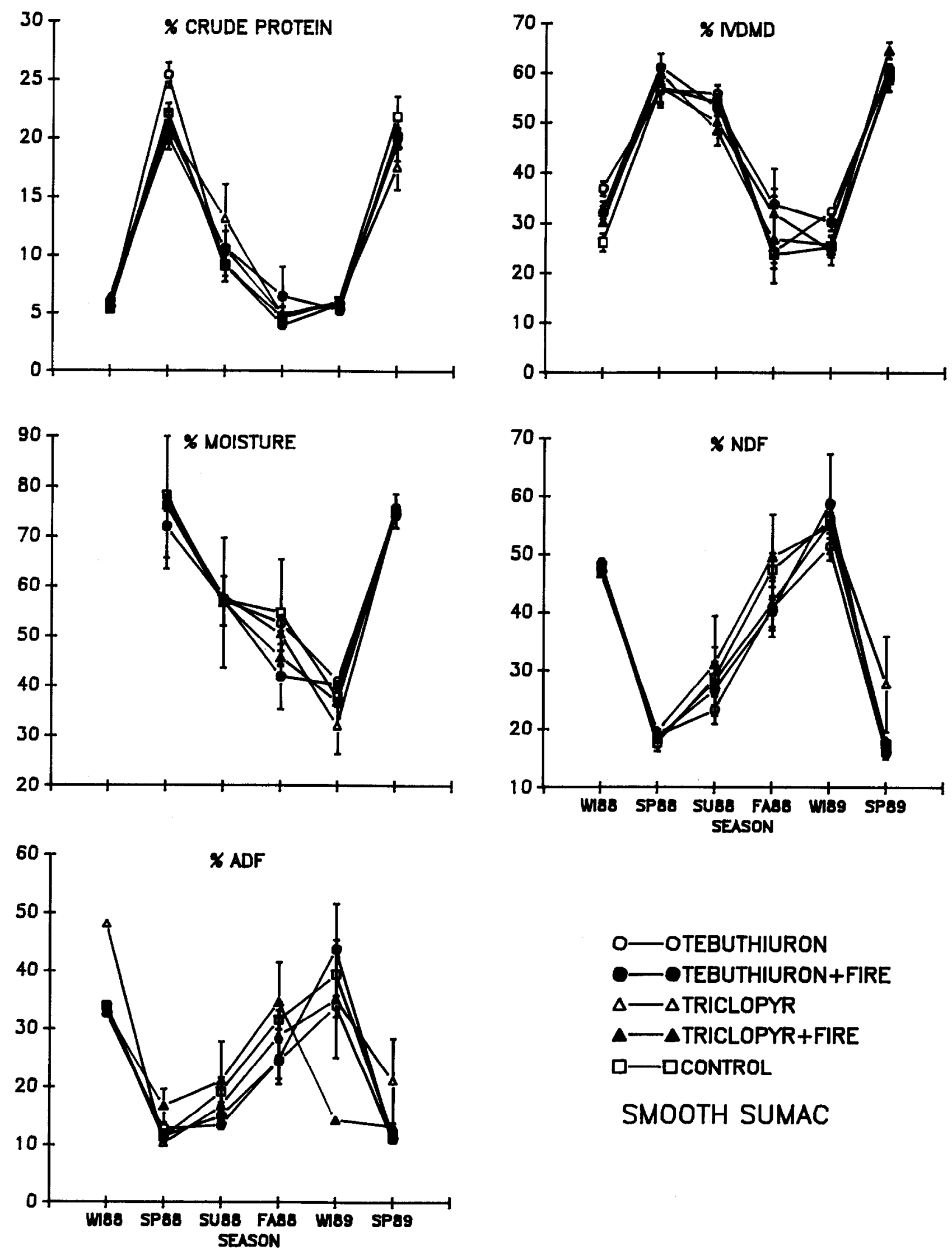

SMOOTH SUMAC

Fig. 6. Seasonal changes in mean $( \pm S E)$ nutrient composition of smooth sumac browse as influenced by experimental brush removal using triclopyr or tebuthiuron with and without prescribed fire. The study was conducted on the Cross Timbers Experimental Range during all seasons in 1988 and winter and spring of 1989. 

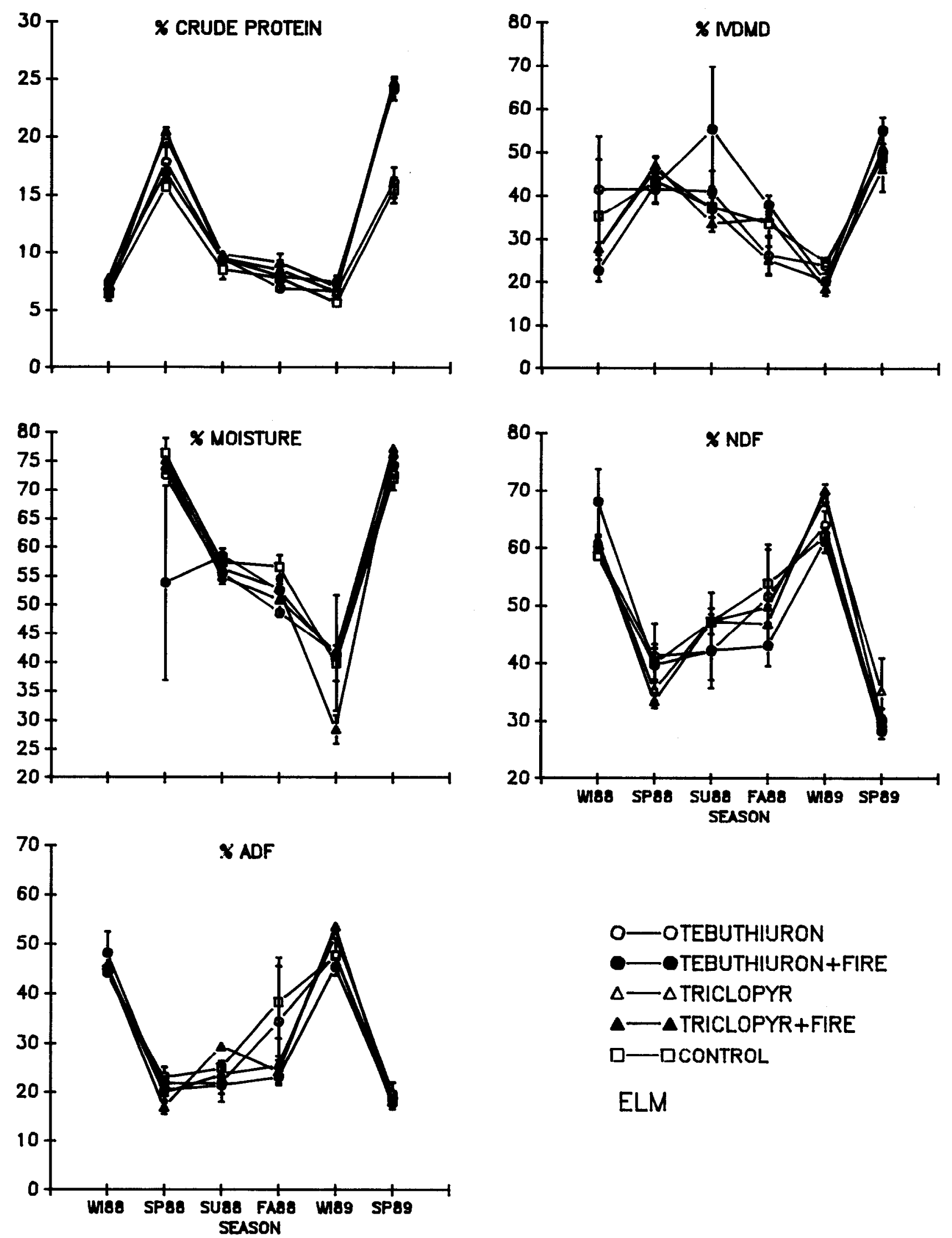

ELM

Fig. 7. Seasonal changes in mean ( $\pm \mathrm{SE}$ ) nutrient composition of elm browse as influenced by experimental brush removal using triclopyr or tebuthiuron with and without prescribed fire. The study was conducted on the Cross Timbers Experimental Range during all seasons in 1988 and winter and spring of 1989. 
Table 1. Nutrient quality indices for 7 common browse species on the Cross Timbers Experimental Range in 1988-89. Specific contrasts made from 4 brush treatments (tebuthiuron and triclopyr with and with out fire) and an untreated control. Data are means from 6 sampling periods (all seasons in 1988, spring and winter 1989).

\begin{tabular}{|c|c|c|c|c|c|c|c|}
\hline \multirow[b]{2}{*}{ Species } & \multirow[b]{2}{*}{ Nutrient ${ }^{2}$} & \multicolumn{6}{|c|}{ Specific contrasts $^{1}(\bar{X} \pm \mathrm{SE})$} \\
\hline & & Treated & vs & Untreated & Tebuthiuron & vs & Triclopyr \\
\hline Coralberry & Crude protein & $9.9 \pm 0.41$ & & $9.2 \pm 0.69$ & $9.1 \pm 0.47$ & & $10.6 \pm 0.65$ \\
\hline Blackberry & $\begin{array}{l}\text { Crude protein } \\
\text { IVDMD } \\
\text { Neutral detergent fiber } \\
\text { Acid detergent fiber } \\
\text { Moisture content }\end{array}$ & $\begin{array}{l}12.1 \pm 0.49 \\
42.4 \pm 1.04 \\
38.6 \pm 1.17 \\
22.2 \pm 1.10\end{array}$ & & $\begin{array}{l}11.4 \pm 1.08 \\
36.9 \pm 2.45 \\
44.7 \pm 3.62 \\
28.4 \pm 3.39\end{array}$ & $11.6 \pm 0.67$ & & $12.8 \pm 0.70$ \\
\hline Dogwood & $\begin{array}{l}\text { Crude protein } \\
\text { IVDMD }\end{array}$ & $\begin{array}{l}10.2 \pm 0.50 \\
43.8 \pm 1.29\end{array}$ & & $\begin{array}{r}9.0 \pm 0.82 \\
40.8 \pm 2.67\end{array}$ & $9.9 \pm 0.66$ & & $10.6 \pm 0.75$ \\
\hline Elm & Crude protein & $12.4 \pm 0.68$ & & $9.9 \pm 0.88$ & $11.6 \pm 0.86$ & & $13.1 \pm 1.04$ \\
\hline Hackberry & $\begin{array}{l}\text { Crude protein } \\
\text { IVDMD }\end{array}$ & $\begin{array}{l}13.6 \pm 0.75 \\
38.4 \pm 1.48\end{array}$ & & $\begin{array}{l}11.3 \pm 1.21 \\
35.8 \pm 2.68\end{array}$ & $12.5 \pm 0.90$ & & $14.8 \pm 1.19$ \\
\hline Greenbriar & $\begin{array}{l}\text { Crude protein } \\
\text { IVDMD } \\
\text { Moisture content }\end{array}$ & $67.1 \pm 1.84$ & & $\begin{array}{l}36.6 \pm 1.43 \\
70.1 \pm 3.60\end{array}$ & $\begin{array}{l}16.5 \pm 1.51 \\
33.7 \pm 2.54\end{array}$ & & $17.7 \pm 1.67$ \\
\hline Smooth sumac & IVDMD & $44.0 \pm 1.58$ & & $40.9 \pm 3.41$ & & & \\
\hline
\end{tabular}

'Each pair of means for a species and nutrient combination is significantly different $(P<0.05)$

${ }^{2}$ Nutrient values expressed as \% dry matter; moisture content expressed as \% fresh tissue.

${ }^{2}$ In vitro dry matter digestibility.

Differences in fiber constituents (neutral and acid detergent fibers) of blackberry were significant among treatments. Specific contrasts showed both neutral detergent fiber (on average $16 \%$ lower) and acid detergent fiber (17\% lower) levels were significantly lower on herbicide-treated areas than untreated controls (Table 1). Fiber concentrations of browse were not influenced by type of herbicide applied or prescribed burning. Treatment differences in moisture content were confined to greenbrier where levels were significantly higher on untreated controls compared to herbicide-treated areas.

\section{Discussion}

Alterations in the nutritional quality of white-tailed deer browse were apparent 5-6 years after experimental herbicide and fire applications to control woody vegetation on the Experimental Range. Crude protein, with concomitant changes in the in vitro dry matter digestibility, were the attributes of browse quality most sensitive to brush management. Although season modified the amplitude of differences among treatments, browse quality was consistently better on herbicide-treated and triclopyr-treated areas compared to untreated controls and tebuthiuron treatments, respectively. Significant interactions between season and treatment for crude protein may reflect changing rainfall patterns where differences were least during periods of water stress (summer). Several researchers have indicated that forage quality increases shortly after initial application of herbicide (Powell and Box 1966, Kirby and Stuth 1982, Masters and Scifres 1984). However, information on long-term effects (Sears et al. 1986) of herbicide treatments on nutritional attributes of browse and other forages used by white-tailed deer are extremely limited and nonexistent for the cross timbers land resource area.

Elucidation of the mechanisms responsible for the observed nutritional benefits of brush management on the Experimental Range are hampered by this information void. However, several factors such as removal of canopy cover (Blair et al. 1983), changes in soil moisture (Laycock and Price 1970), and nutrient release (Sears et al. 1986) could act singly or in concert to maintain post-treatment differences in nutritional quality of browse. Sears et al. (1986) noted that soil nitrogen concentrations and soil organic matter increased on tebuthiuron-treated areas 6 years post-treatment in the sand shinnery oak communities of northern Texas. They attributed the nitrogen increase to the increase in forb production, decaying litter, and oak death/decomposition. Similarly, persistent elevations of crude protein in browse on the Experimental Range may reflect a slow release of nitrogen into the soil from decaying overstory biomass on treated areas.

In vitro dry matter digestibility resembled changes in crude protein on the Experimental Range in response to herbicide applications. Although not as evident, a similar trend was apparent for browse collected from triclopyr-treated areas compared to tebuthiuron-treated areas. Van Soest (1982) indicated that protein is positively associated with digestibility. Although not as sensitive to treatment, fiber constituents (neutral and acid detergent fibers) of a limited number of browse species were lower on herbicidetreated areas as one would expect with an increase of crude protein and in vitro dry matter digestibility (Van Soest 1982).

Burning had little impact on browse quality on the Experimental Range and was limited to increased crude protein for elm. Insufficient fuel loads on the Experimental Range made burning of limited use for secondary brush control on triclopyr treatments, but was more effective on tebuthiuron treatments (Engle et al. 1991). Previous researchers have shown that nutritional responses of browse to periodic burning are variable and depend on fire intensity, ranging from relatively minor and short-lived increases (Wood 1988) to more substantial and persistent improvements in quality following high-intensity burns (Dewitt and Derby 1955).

Seasonal fluctuations in crude protein values have been well documented on undisturbed sites (Short et al. 1975, Blair et al. 1980, Happe et al. 1990). Seasonal crude protein, in vitro dry matter digestibility, and moisture content values were highest in spring and summer but declined as plants matured in fall and winter. Conversely, fiber constituents increased as plants matured. Everitt (1983) documented that seasonal nutrient rhythms associated with plant development did not differ between shredded (mechanical brush control) and nonshredded woody browse in south Texas. Our results, as evidenced by a small number of significant season $X$ treatment statistical interactions, indicated 
that seasonal cycles of browse quality were also not affected appreciably by brush management practices on the Experimental Range. When significant interactions were present, treatment differences appeared to be more prevalent in winter and spring during the early phenological stages of development. All treated areas on the Experimental Range had seasonal crude protein values above the estimated 6 to $7 \%$ maintenance levels required for white-tailed deer (French et al. 1965).

Thill and Morris (1980) noted that deer in southern upland forests generally are limited by forage quality and not forage quantity. Our results indicate that nutritional quality of common white-tailed deer browse in the cross timbers of central Oklahoma can benefit over the long-term ( 6 years post-treatment) from range improvement practices incorporating the use of triclopyr or tebuthiuron. Overall crude protein values (data pooled across species, seasons, and years) averaged $5 \%$ greater on tebuthiuron and $10 \%$ greater on triclopyr treatments compared to untreated controls. These results do not reflect production of woody browse, which was also influenced by management techniques-increased on triclopyr treatments and decreased on tebuthiuron treatments, relative to controls.

Although triclopyr provided better long-term nutritional benefits than tebuthiuron, limited improvements in herbaceous forage production (mostly forbs and browse) following triclopyr application would make this a less attractive alternative than tebuthiuron (greater grass production) for most livestock producers (Engle et al. 1991). Economic models incorporating lease hunting of deer and multiple livestock enterprises indicate tebuthiuron, triclopyr, and prescribed burning in combination will optimize returns in the cross timbers (Bernardo et al. 1992). Landowners wishing to improve quality of rangeland for both livestock and deer may wish to consider the application of both herbicides (variable herbicide patterning) to create a mosaic of habitat types (Scifres and Koerth 1986, Bernardo et al. 1992, Soper et al. 1992).

\section{Literature Cited}

Bernardo, D.J., D.M. Engle, R.L. Lochmiller, and F.T. McCollum. 1992. Optimal vegetation management under multiple-use objectives in the Cross Timbers. J. Range Manage. 45:462-467.

Blair, R.M., H.L. Short, L.F. Burkhart, A. Harrell, and J.B. Whelan. 1980. Seasonality of nutrient quality and digestibility of three southern deer browse species. USDA Forest Serv. Res. Pap. SO-161. US Gov. Print. Off., Washington, D.C.

Bogle, L.A., D.M. Engle, and F.T. MeCollum. 1989. Nutritive value of range plants in the cross timbers. Oklahoma Agr. Exp. Sta. Res. Rep. P-908.

Choo, G.M., P.G. Waterman, D.B. Mckey, and J.S. Gartlan. 1981. A simple enzyme assay for dry matter digestibility and its value in studying food selection in generalists herbivores. Oecologia 49:170-178.

Cowan, R.L., J.S. Jordan, J.L. Grimes, and J.D. Grimes. 1970. Comparative nutritive values of forage species, p. 48-56. In:H.A. Paulsen, Jr., and E.H. Reid (eds.), Range and wildlife habitat evaluation-a research symposium. USDA Agr. Misc. Pub. 1147, US Gov. Print. Off., Washington, D.C.

Deliberto, D.J. 1987. Nutritional ecology of white-tailed deer in southcentral Oklahoma. M.S. Thesis Texas Tech., Univ., Lubbock.

Dewitt, J.B., and J.V. Derby, Jr. 1955. Changes in nutritive value of browse plants following forest fires. J. Wildl. Manage. 19:65-70.

Engle, D.M., J.F. Stritzke, and F.T. McCollum. 1991. Vegetation management in the cross timbers: Response of understory vegetation to herbicides and burning. Weed Tech. 5:406-410.

Everitt, J.H. 1983. Effects of plant shredding on nutrient content of four south Texas deer browse species. J. Range Manage. 36:779-781.

Ewing, A.L., J.F. Stritzke, and J.D. Kulbeth. 1984. Vegetation of the cross timbers experimental range, Payne County, Oklahoma. Okla. Agr. Exp. Sta. Res. Rep. P-586.

French, C.E., L.C. McEwen, N.D. Magruder, R.H. Ingram, and R.W. Swift. 1956. Nutrient requirements for growth and antler development in white-tailed deer. J. Wildl. Manage. 20:221-232.
Gee, K.L., M.D. Porter, S. Demaris, F.C. Bryant, and G. Van Vreede. 1991. White-tailed deer: their foods and management in the cross timbers. Samuel Roberts Noble Foundation Misc. Pub. Samuel Roberts Noble Foundation, Ardmore, Okla.

Garrison, G.A., A.J. Bjugstad, D.A. Duncan, M.E. Lewis, and D.R. Smith. 1977. Vegetation and environment features of forest and range ecosystems. USDA Forest Serv. Agr. Handb. 475, US Gov. Print. Off., Washington, D.C.

Goering, H.K., and P.J. Van Soest. 1970. Forage fiber analyses (apparatus, reagents, procedures, and some applications). USDA Agr. Handb. 379, US Gov. Print. Off., Washington, D.C.

Gray, F., and C. Stanke. 1970. Classification of soils in the savanna-forest transition in eastern Oklahoma. Oklahoma Agr. Exp. Sta. Bull. B-672.

Halls, L.K., and E.A. Epps, Jr. 1969. Browse quality influenced by tree overstory in the south. J. Wildl. Manage. 33:1028-1031.

Happe, P.J., K.J. Jenkins, E.E. Starkey, and S.H. Sharrow. 1990. Nutritional quality and tannin astringency of browse in clear-cuts and oldgrowth forests. J. Wildl. Manage. 54:557-566.

Hundley, L.R. 1959. Available nutrients in selected deer-browse species growing on different soils. J. Wild1. Manage. 23:81-90.

Ivey, T.L., and M.K. Causey. 1984. Response of white-tailed deer to prescribed fire. Wildl. Soc. Bull. 12:138-141.

Jenks, J.A. 1991. Effect of cattle stocking rate on the nutritional ecology of white-tailed deer in managed forest of southeastern Oklahoma and southwestern Arkansas. Ph.D. Thesis, Oklahoma State Univ., Stillwater.

Kirby, D.R., and J.W. Stuth. 1982. Brush management influences the nutritive content of cattle diets in east-central Texas. J. Range Manage. 35:431-433.

Laycock, W.A., and D.A. Price. 1970. Environmental influences on nutritional value of forage plants, p. 37-47. In: H.A. Paulsen, Jr. and E.H. Reid (eds.), Range and wildlife habitat evaluation-A research symposium. USDA Misc. Pub. 1147, US Gov. Print. Off., Washington, D.C.

Lochmiller, R.L., J.F. Boggs, S.T. McMurry, D.M. Leslie, and D.M. Engle. 1991. Response of cottontail rabbit populations to herbicide and fire applications on cross timbers rangeland. J. Range Manage. 44:150-155.

Masters, R.A., and C.J. Scifres. 1984. Forage quality responses of selected grasses to tebuthiuron. J. Range Manage. 37:83-87.

McCollum, F.T., D.M. Engle, and J.F. Stritzke. 1987. Brush management on the cross timbers experimental range: III. Carrying capacity and steer performance. Oklahoma Agr. Exp. Sta. Res. Rep. MP-119.

Powell, J., and T.W. Box. 1966. Brush management influences preference values of south Texas woody species for deer and cattle. J. Range Manage. 19:212-214.

Rasmussen, G.A. C.J. Scifres, and D.L. Drawe. 1983. Huisache growth, browse quality and use following burning. J. Range Manage. 36:337-342.

Robbins, C.T., and A.N. Moen. 1975. Composition and digestibility of several deciduous browses in the northeast. J. Wildl. Manage. 39:337-341.

S A S Procedures Guide. Statistical analysis system. 1985. S AS Institute Inc., Raleigh, N.C.

Sears, W.E., C.M. Britton, D.B. Wester, and R.D. Pettit. 1986. Herbicide conversion of a sand shinnery oak (Quercus havardii) community: effects on nitrogen. J. Range Manage. 39:403-407.

Scifres, C.J. 1980. Brush management: principles and practices for Texas and the southwest, 1st ed. Texas A\&M Press, College Station.

Scifres, C.J., and B.J. Koerth. 1986. Habitat alterations in mixed brush from variable rate herbicide patterns. Wildl. Soc. Bull. 14:345-356.

Scifres, C.J., and J.L. Mutz. 1978. Herbaceous vegetation changes following applications of tebuthiuron for brush control. J. Range Manage. 31:375-378.

Scifres, C.J., J.L. Mutz, and W.T. Hamilton. 1979. Control of mixed brush with tebuthiuron. J. Range Manage. 32:155-158.

Scifres, C.J., J.R. Scifres, and M.M. Kothmann. 1983. Differential grazing use of herbicide treated areas by cattle. J. Range Manage. 36:65-69.

Scifres, C.J., J.W. Stuth, and R.W. Bovey. 1981. Control of oaks (Quercus spp.) and associated woods species on rangeland with tebuthiuron. Weed Sci. 29:270-275.

Short, H.L., R.M. Blair, and E.A. Epps. 1975. Composition and digestibility of deer browse in southern forests. USDA Forest Serv. Res. Pap. SO-111. US Gov. Print. Off., Washington, D.C.

Soper, R.B., R.L. Lochmiller, D.M. Leslie, and D.M. Engle. 1993. Condition and diet quality of white-tailed deer in response to vegetation management in central Oklahoma. Proc. Oklahoma Acad. Sci. (In Press).

Soil Conservation Service. 1981. Land resource regions and major land resource areas of the United States. USDA Agr. Handb. 296. US Gov. Print. Off., Washington, D.C. 
Stritzke, J.F., D.M. Engle, and F.T. McCollum. 1991. Vegetation management in the cross timbers: responses of woody species to herbicides and burning. Weed Tech. 5:400-405.

Thill, R.E., and H.F. Morris. 1990. Nutritional quality of deer diets from southern pine-hardwood forests. Amer. Midl. Natur. 124:413-417.

Van Soest, P.J. 1982. Nutritional ecology of the ruminant. Cornell Univ. Press, Ithaca, N.Y.
Van Vreede, G. 1987. Seasonal diets of white-tailed deer in south-central Oklahoma. M.S. Thesis, Texas Tech Univ., Lubbock.

Williams, S., (ed.) 1984. Official methods of analysis of the Association of Official Analytical Chemists. Fourteenth ed. Assoc. Off. Anal. Chem., Washington, D.C.

Wood, G.W. 1988. Effects of prescribed fire in deer forage and nutrients. Wildl. Soc. Bull. 16:180-186. 